ВИРУСЫ И КЛЕТКА

\title{
DNA-containing phages neutralizing with anti-MS2 serum
}

\author{
Tamara $P$. Pererva \\ Itustitute of Molecular Biology ard Genesics, Notional Academy of Sciences of Ukraine \\ 1.50 Acad. Zabclotnogo str., Kyiv, 252143, Ukraine
}

The DNA-containing phages neutralizing with anti-MS2 serum have been defected in MS2-induc: bacterial cultures, in the cells containing the recombinant plasmid as well as in preparitions of trunsitucins lambda and $P I$ phages. The identity of all these new developed bacteriophages pernits so suppose tha crommon mechanism of their origin.

V/e have estrier described the induction of MS2resistant forms in the offspring of an Escherichia coli A.B $259 \mathrm{Hfr} 3000$ cell having survived this phage infection 11 !. The phage-induced mutants have been shown to be genetically unstable ones; they are able to segregale new mutant lypes: two of them, a granular mulant and a lysing one, have been studied in detail [2]. The cloning of the mutant region in a non-replicating Ap-fragment [3] has demonstrated the some possibility of integration of an MS2-specific sequence with the $E$. coli cell DNA; such a result induces to study these mutanis from the new point of view of RNA phages-host cell interaction problem as origin and properties of these mutants suggested the presence at least of a part of phage genome or its IJNA copy in their chromosome. The attempts to find the association of MS2-specific nucleic acid with the host cell chromosome las been made using the method of bybridization of MS2-induced mutant RNA and DNA with MS2 cDNA [4] and by the genetic transfer of the mutant properties into the lambda phage chromosome [5]. Despite of some positive riesults we have failed to detect the presence of MS2 phage in MS2-induced mutant cells or the phage siscretion by these cells. Such phenomena do not correlate with the well-known traditional lysogeny conception as well as with the persistant state conception because in both these cases bacterial cultures contain some cluantity of free phage. At the same time, such fact as DNA-containing MS2-derivative

(c) T. $r$ PEKLKYA, t'9y8 phages segregation in the course of transducing $\mathrm{Pl}$ and lambda phages reproduction 15] suggest th anti-MS2 serum neutralizing phages migh1 have bee? detected in MS2-induced mutant celis of granular and lysing types. The aim of this work was revealing of DNA-containing phages with some MS2-like properties and comparison of these properties with ones of phage segregants described carlicr $[5]$.

Indeed a prolongated observation of wild lype is. coli 3000 cells put in the medium togetler with lysing and granular type mutants permits to detect a phay: whose development goes with the exiremely low frequency. If a drop of an one-day-old $E$. coli 3000 or of another F-pili forming culture is put on the lawn formed by any of these two mutants a spot region of the wild type lawn becomes markedly clearer in several days. Some additional passages of the material isolated from the spot give us the possibility to detect the phages being identical and possessing the host range of the MS2 phage. Contrary to phages appearing in $\mathrm{QB}-$ and MS2-resistant $\mathrm{fi}+F^{2}$. coli cultures $[6,7]$ the phage particles found in our test-system are markedly different in their size and morphology from the MS2 phage; these particles arc DNA-containing and consisted of heads and taili;: they have been neutralized by the anti-MS2 scruni, the neutralization level being the same as with the native MS2 phage. Neutralization constants were 285. 267, 230 and 293 for MS2, phage segregated from lysing bacterial mutant, phage segregated from granu. lar mutant and phage segregated from recombinani plasmid-containing culture accordingly. Inmunization 
of rabbits was made according to Adams 181 and preliminary purifying of MS2 phage in $\mathrm{CsCl}$ gradient was made according to Maniatis of al. [9]. Anti MS2-serum obtained in such a way did not neutralise phages $P l$ and $\lambda$ as well as it did not agglutinate $E$. coli 3000 host cells. On the other side anti-serums against phages $\lambda$ and $\mathrm{Pl}$ and to $E$. coli 3000 cells did not ncutralise both $\mathrm{MS} 2$ phage and all the new JNA-contained phages obtained in the process of this work. Exhaustion of anti MS2-serurr by MS2 phage preparations having different phage particles concentrations decreased neutralizing properties of serum both to MS2 phage and to DNA-containing phages described here; in the ases when the high-titre MS2 phage was usted for exhaustion neutralizing properties of serum disappeared completely and all tested phages (both RNA- and DNA-containing ones) formed negative colonites in the presence of such exhausted anti MS2-scrum. It should be noted that these data confirm only the activity of anti MS2-scrum to new phages but don't exlude the possibility of the presence of some other antigens on the surface of these phages. This problem will be investigated by us in the further experiments. It is clear from our electron microscopic photoes of MS2 derivative phage particles having been mixed with the T'4 phage (Fig. 1) and
MS2 phage (Fig. 2) that the derivative particles are markedly larger comparing to the MS2 ones. Their' icosahedrical head having a diameter about $50 \mathrm{nn}$. and their tails being about $150-160 \mathrm{~nm}$ long. Despitt: of these particles strict specificity for donor type cells, our electron microscopic investigations detect no derivative particles adsorption on F-pili. The ciuse of this phenomenon is supposed to be elucidated in further investigations. At the same time such particles form negative colonies belonging to the same type as the colonies formed by PI and lambda transducing phages segregants $[5]$. Despite of the bacterial lawn ageing, the colonies of DNA-containing MS2 de. vative phages become larger during several dist the demi-lysis zones becoming also wider and occupin: the whole lawn. The cells containing the rucombinat? plasmid pL34 constructed by us 13 | also accumblati. the DNA-containing phage identical 10 those wi found in MS2-induced mutants from the point of vis $w$ of its morphology, its neutralization with anti-MS2 serum, and its restriction obtained after resirtction nucleases treatment (sec Fig. 3). The identicat D) $\backslash 4$. containing particles are also found in MS2 pro parations, such an identity having been proved by th: markers already described above for othur inA containing phages neutralizing with anti-MS2 sirusti.

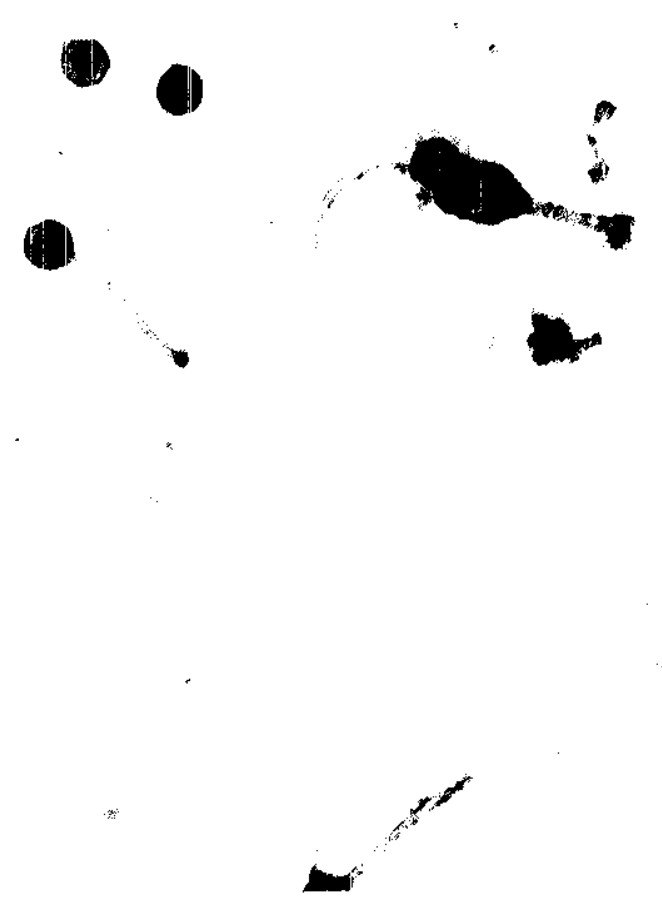

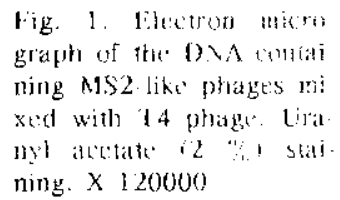




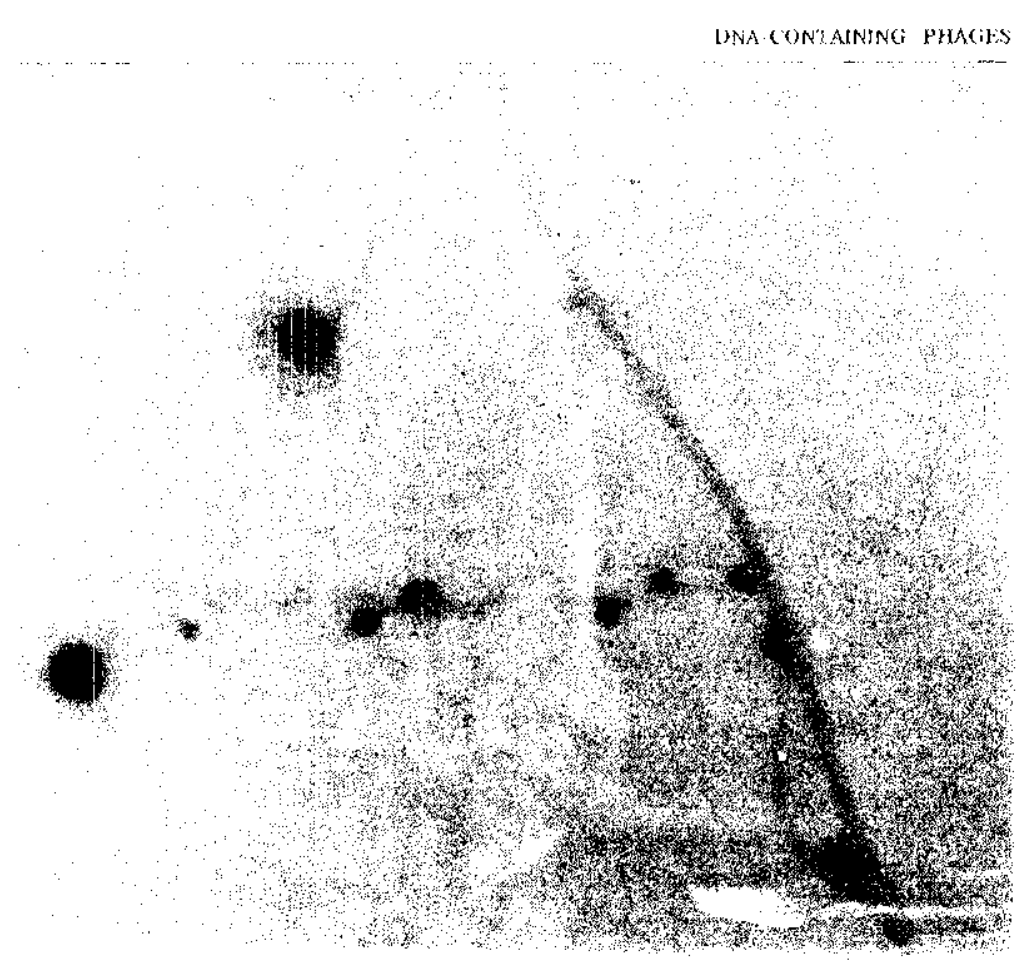

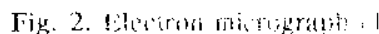
the DNA contalining MSZ lit. phage particles mixed wir.

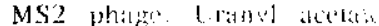
(2) staining. $x$ i 20000

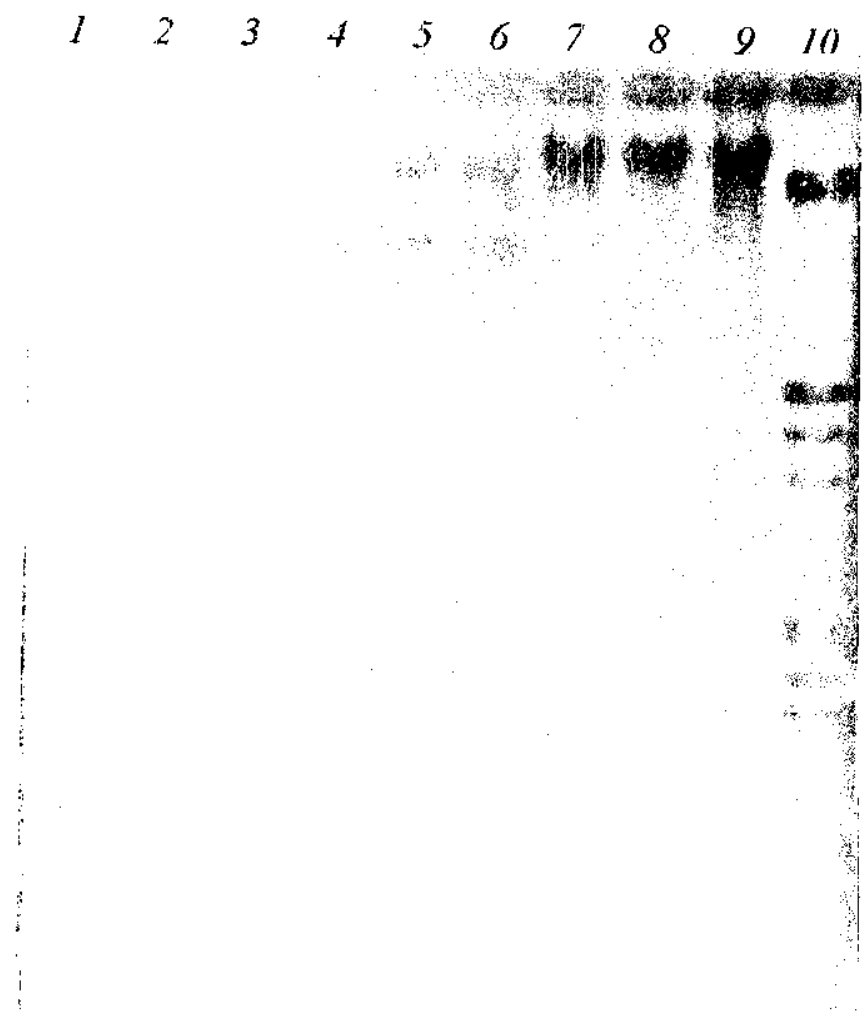

f"g. 3. Llectrophuregram of the DNAs isclated thom MS2-like phages and digested with restrictascs flaeill $\left.(1--3), p_{s t} / 4-6\right)$, and

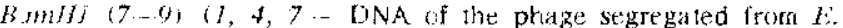
coli 3000 bysing type mutant; $2,5,8$-- DNA of the phage se gregaled from $l:$ coli granular muknt; $3,6,9 \ldots$ DNA from the phage segrigaled from fil.34 contanitug celis): 16) -... lambda pbage

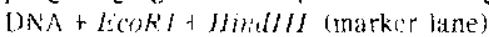

The formation of DNA-contaning flicks MS2-induced $E$. coli mutants suggessis once more titit some processes well known and invertigated in detait may be accompanied with some other events of it vere low frequency followed by new biological formis hirt being new virus forms in our casc. Contrary $w$ retrovirus-cell systems, no DNA-containinge structures taking part in RNA-containing phages repreduction: and phage RNA replication have becrn yel describes. Additionally, the construction of revertas:-firtget MS2 DNA in vitro is completely impossible withoul antificial connection of the poly (dA) poly (dT)-linke to MS2 phage RNA $\{10\}$ being inaccessible tor the enzyme without such a supplement. So it minot b ruled out that the process of formation of DNA. containing phages antigenically related or identical to RNA-containing ones may be due to other minchat nisms of RNA-DNA interactions perhaps trome simila. to those described previously for from an wis [11]. It cannot be ruled out that the prescrice in the bacterial cell of RNA-phage specific information ind:pendently of its form (phage multiplication or som other form specific for MS2-induced cell mulation: induces prophages presented in $E$. coll colls chrome somes and plasmids. Such a prophage sequence bas: form hybride forms with RNA phages components both on the level of genomes and MS2-specific protein coating of phage particles with new propertics.

In any case, we have data enough to assume the new virus-host cell interaction ideas are atceptabl wo 
RNA-containing bacteriophages, at least at the structural level, and may be successfully detected in a system of MS2-induced cellular and phagic mutants.

Acknowledgement. The author thanks Dr. F. T'ovkatch for the preparation of clectron microscopic photos, $\mathrm{D}_{i}$. Anna Miriuta for the restrictive analysis of the phage DNAs, and Dr. Ella Zhirebtsova having prepared the anti-phage serum and helped to prepare this manuscript.

\section{T. П. Hepepoir}

ДНК-гіміспі фати, гұо нейтралізуютьсы анти-MS2 сироваткою

PezTOM

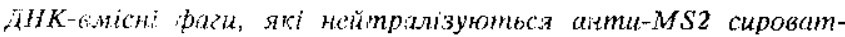

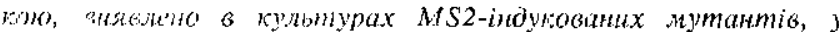

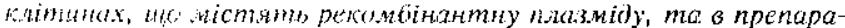

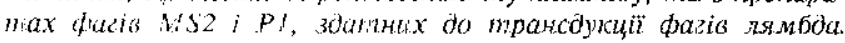

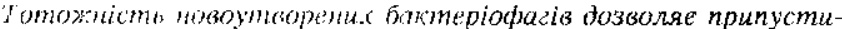

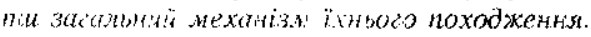

\section{i. II. Ileperosis}

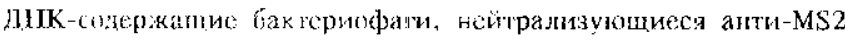

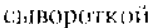

Peзюм:

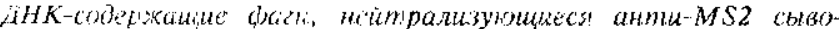

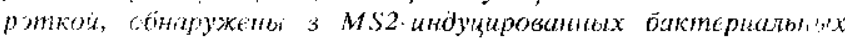

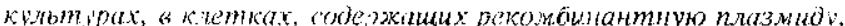

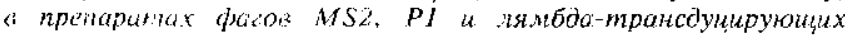

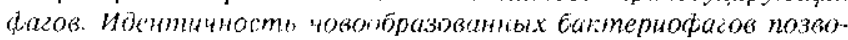

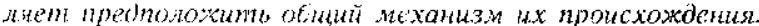

\section{REFERENCES}

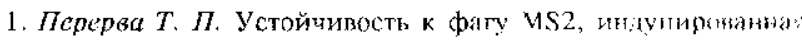
у E. coli при заражении этим фатом // /итопмия " генетика.-1977.-11, № 1.-C. 3-9.

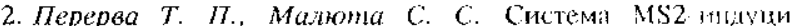

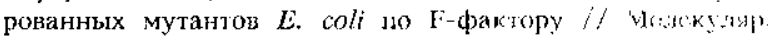
биология.-Киев: Наук. думка, 1984.--Bm. 3s. (С. 81. 90

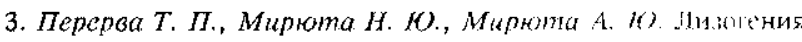

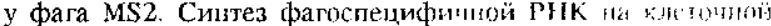

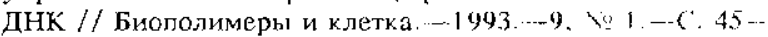
50.

4. Pererva T. P., Miriuta N. Yu, Mirinta A. Yll at Analysis of a recombinant plasmid containing MS2-like se(puctec if Ibid. $-1995 .-11, \mathrm{~N} 1, \ldots \mathrm{P}, 61 \cdots 65$.

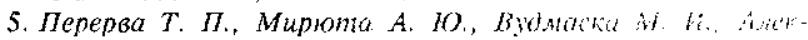

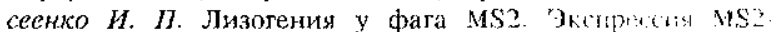

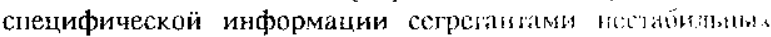

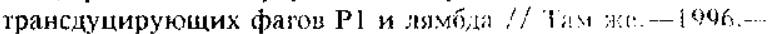
12, № 4.-C. 73-83.

6. Widmer H. R., Lebec $G$. Der Einfluss wo R SS phagen aid Konjugationsfaktoren // Pathol. Microbiol...-1974, 40, N 3 4. - S. $153-154$.

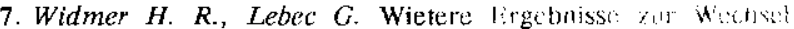

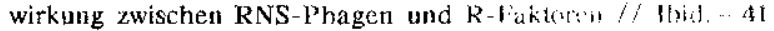
N 3-4. -S. 194-195.

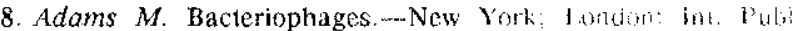
Inc., 1951.

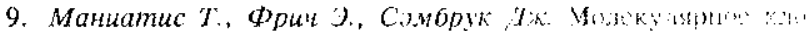
нирование--М.: Мир, 1984.

10. Devos R., Van Emmelo J., Contreras R. Figs le t.msill

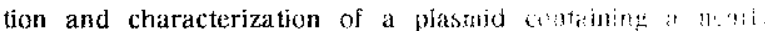

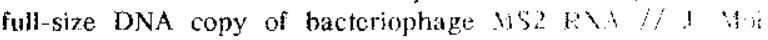
Biol. -1979. $-\mathrm{N}$ 4.-P. 595-619

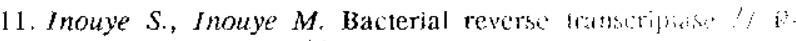
verse Transcriptase // Eds $\Lambda$. If. Skatha. S. f G Gia ... York: Cold Spring Harb. Lab. press, 1903.......44.

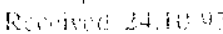

